\title{
Chyle Leak Following Axillary Lymph Node Clearance - a Benign Complication: Review of the Literature
}

\author{
John Taylor Samira Jayasinghe Ludger Barthelmes Mike Chare \\ Breast Unit, Department of Surgery, Singleton Hospital, Swansea, UK
}

\section{Keywords}

Breast cancer - Complication - Lymph node dissection . Parenteral nutrition - Breast neoplasm - Axillary clearance

\section{Summary}

Case Report: An 82-year-old patient underwent a mastectomy and axillary lymph node clearance for a large multicentric lobular cancer of the left breast. On day 11 after her operation, white viscous fluid was noted in her axillary drain. Methods: We analysed case reports in the literature, noting the interval between surgery and diagnosis of chyle, the duration of the chyle leak, the volume of chyle during the first $24 \mathrm{~h}$, the median volume and the administered treatment. Results: 25 cases were reported in 13 publications. Our case was unusual in that chyle was noted 11 days after surgery. In most cases, chyle leakage subsides spontaneously by simply leaving the drain in situ. Conclusions: A conservative observant approach appears appropriate in most cases. Only for persistent and large-volume leaks, dietary intervention (medium-chain lipid diet, nil by mouth, total parenteral nutrition) is justified. Surgery with re-exploration of the axilla and oversewing of the chyle duct can be used as the last reserve for persistent chyle leaks.

\section{Introduction}

Seroma formation and leakage of lymphatic fluid are expected side effects following an axillary lymph node clearance. Change of the drain fluid to a viscous white fluid promp-

\section{Schlüsselwörter}

Brustkrebs · Komplikation · Lymphknotenausräumung · Ernährung, parenterale · Lymphknotenausräumung, axilläre $\cdot$ Chylusfistel

\section{Zusammenfassung}

Fallbericht: Eine 82-jährige Frau unterzog sich einer Mastektomie und axillären Lymphknotenausräumung wegen eines fortgeschrittenen lobulären Karzinoms der linken Brust. Am 11. postoperativen Tag wurde eine weiße visköse Flüssigkeit in der axillären Drainage festgestellt. Methoden: Wir analysierten Fallberichte in der Literatur im Hinblick auf den Zeitraum zwischen Operation und Diagnose des Chylus, der Dauer der Chylusfistel, des Chylusvolumens während der ersten $24 \mathrm{~h}$, des durchschnittlichen Chylusvolumens und der Behandlung. Ergebnisse: 25 Fälle wurden in 13 Veröffentlichungen beschrieben. Unser Fall war ungewöhnlich, da Chylus erst am 11. postoperativen Tag festgestellt wurde. In den meisten Fällen geht die Chylusfistel bei kontinuierlicher axillärer Drainage spontan zurück. Schlussfolgerungen: In den meisten Fällen ist konservatives Zuwarten angebracht. Ein diätetischer Eingriff (mittelkettige LipidDiät, komplette parenterale Ernährung) ist nur bei hohem, persistierendem Fistelvolumen angebracht. Eine Operation mit erneuter Exploration der Axilla und Übernähen des Chylusgefässes ist ein letztes Reservemittel bei persistierender Chylusfistel.

ted testing for triglyceride levels in fluid and serum and led to the diagnosis of a chyle leak. We compare our case with the literature and outline management options.

\section{KARGER \\ Fax +497614520714 \\ Information@Karger.de}

www.karger.com

\section{(c) 2011 S. Karger GmbH, Freiburg}

$1661-3791 / 11 / 0062-0130 \$ 38.00 / 0$

Accessible online at:

www.karger.com/brc
Dr. Ludger Barthelmes

Breast Unit, Department of Surgery

Cumberland Infirmary

Carlisle CA2 7HY, UK

Tel. +44 1228 81-4229, Fax -4101

barthelmes@tinyonline.co.uk 


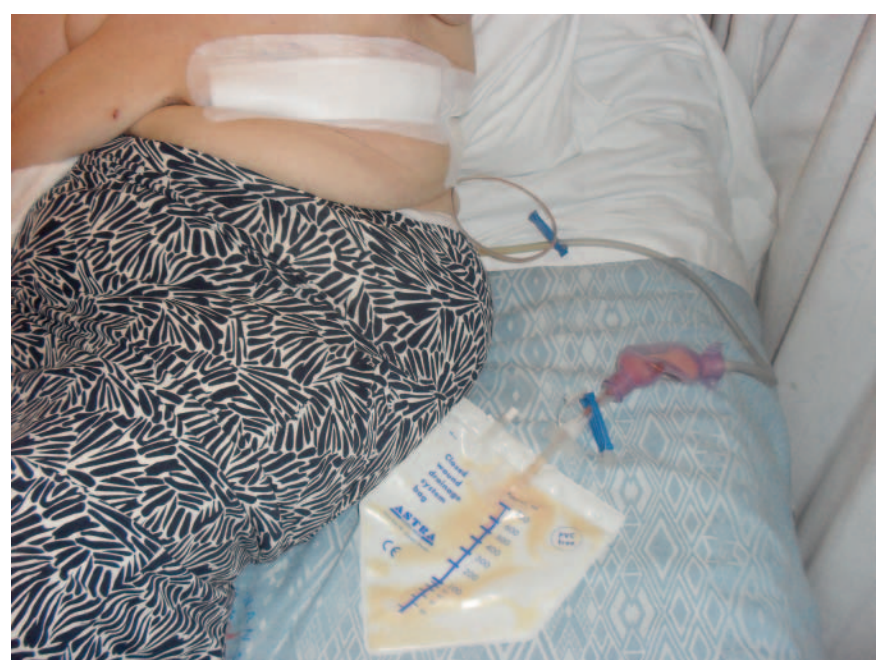

Fig. 1. Day 11 after left mastectomy and axillary node clearence. White viscous drain fluid with elevated triglyceride levels establishing the diagnosis of chyle.

\section{Case Report}

An 82-year-old lady underwent a mastectomy and axillary lymph node clearance for a large multicentric lobular cancer of the left breast. On day 11 after her operation, white viscous fluid was noted in her axillary drain (fig. 1). Until then, drainage had consisted of $90-250 \mathrm{ml} / 24 \mathrm{~h}$ of typical serous fluid. Fluid sent for microscopy revealed a moderate amount of white blood cells. Gram stain and culture did not reveal any organisms. Triglyceride levels of the fluid measured $3.9 \mathrm{mmol} / \mathrm{l}$, i.e. 3 times the serum level $(1.3 \mathrm{mmol} / \mathrm{l})$, which established the diagnosis of chyle. Initially, $120 \mathrm{ml}$ drained during $24 \mathrm{~h}$. Suction was released, output reduced to $20 \mathrm{ml}$ over the following 24-h period and the drain was removed. The patient was well and did not experience any noticeable fluid collection in her axilla after removal of the drain

\section{Methods}

This unusual complication prompted us to search MEDLINE and EMBASE using the medical subject headings (MeSH) 'axillary clearance' and 'chyle' and handsearching the references. We analysed the case reports, noting the interval between surgery and diagnosis of chyle, the duration of the chyle leak, the volume of chyle during the first $24 \mathrm{~h}$, the median volume and the administered treatment.

\section{Results}

We identified 13 publications reporting on 25 cases including our own (table 1). Our case was unusual in that chyle was noted 11 days after surgery. The majority of chyle leaks occur during the first days after the operation ( 8 of 19 recorded cases on the first post-operative day, 5 on the second, 5 between the third and fifth post-operative day (table 1)). The median duration of chyle leak is 7 days. Of 11 patients where the level of axillary dissection was recorded, 4 patients had a level III and 7 patients had a level II clearance. In most cases, chyle leakage subsided spontaneously by simply leaving the drain in situ [1-3]. Treatment of the chyle leakage required surgery in 2 cases $[4,5]$. In our case, chyle leakage subsided spontaneously by simply leaving the drain.

\section{Discussion}

Discovery of chyle following an axillary dissection is unusual as the thoracic duct is remote from the site of dissection. Nonetheless, in 3 series, a chyle leak occurred in $0.47 \%$ (4/851), $0.68 \%(6 / 882)$ and $0.84 \%$ (5/591) of axillary clearances [6-8]. Discovery of chyle drainage following axillary dissection is surprising as the thoracic duct is not thought to be related to the axilla. There is, however, considerable anatomical variation of the thoracic duct. Usually, it drains into the internal jugular or subsclavian vein, but it can also join the external jugular or innominate vein. $30 \%$ of thoracic ducts branch along the course [9]. In $4 \%$ of cases, the duct anastomoses to the venous system via multiple terminations [10]. In 2 of 344 lymphoscintigraphies $(0.6 \%)$ drainage into the left axilla was noted [11]. Injury to an aberrant branch of the thoracic duct during axillary dissection could therefore lead to a chylous leak.

Four patients had a level III and 7 patients had a level II clearance. Purkayastha et al. [5] observed chyle leakage at the time of its surgical repair at level I. A more aggressive dissection may not necessarily put the patient at an increased risk of this complication.

Despite the anatomic variation, one would expect a chyle leak to occur after a left-sided axillary dissection. However, 2 cases have been noted on the right side [7].

\section{Conclusions}

Due to the small number of reported cases, evidence for the optimal management of chyle leakage after axillary dissection is limited and anecdotal. As in most cases the chyle leak subsides spontaneously, a conservative observant approach appears to be appropriate. Only for persistent and largevolume leaks, dietary intervention (medium-chain lipid diet, nil by mouth, total parenteral nutrition) is justified. Surgery with re-exploration of the axilla and oversewing of the chyle duct can be used as the last reserve for persistent chyle leaks. There does not appear to be any added advantage for preoperative imaging with lymphoscintigraphy, but it may give further information of any anatomic variation of the thoracic duct [12].

\section{Disclosure Statement}

The authors declare no conflict of interest. 
Table 1. Chyle leak after axillary lymph node dissection

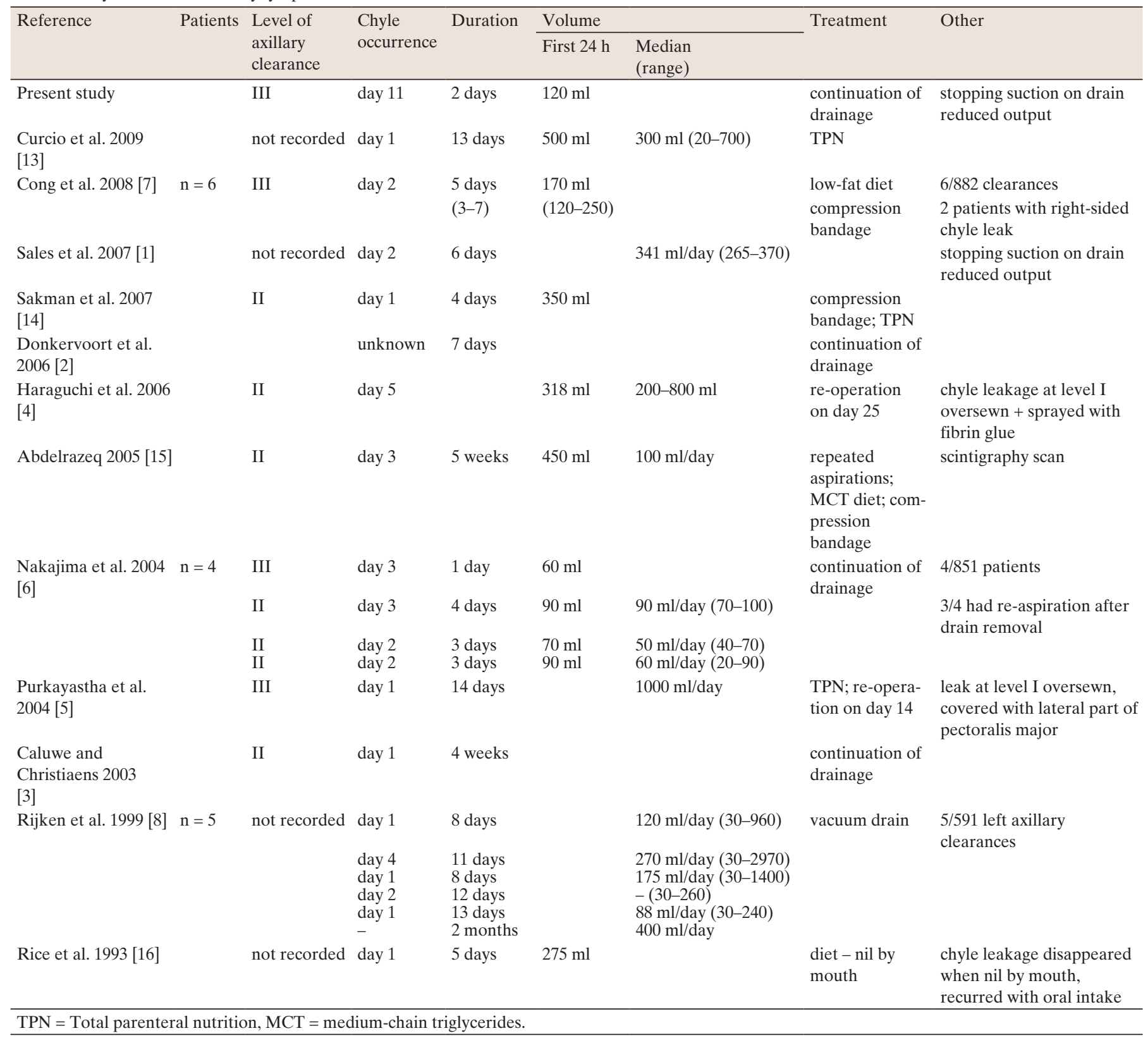

\section{References}

1 Sales F, Trepo E, Brondello S, Lemaitre P, Bourgeois P: Chylorrhea after axillary lymph node dissection. Eur J Surg Oncol 2007;33:1042-1043.

2 Donkervoort SC, Roos D, Borgstein PJ: A case of chylous fistula after axillary dissection in breastconserving treatment for breast cancer. Clin Breast Cancer 2006;7:171-172.

$\checkmark 3$ Caluwe GL, Christiaens MR: Chylous leak: a rare complication after axillary lymph node dissection. Acta Chir Belg 2003;103:217-218.

4 Haraguchi M, Kuroki T, Tsuneoka N, Furui J, Kanematsu T: Management of chylous leakage after axillary lymph node dissection in a patient undergoing breast surgery. Breast 2006;15:677-679.

$\checkmark 5$ Purkayastha J, Hazarika S, Deo SV, Kar M, Shukla NK: Post-mastectomy chylous fistula: anatomical and clinical implications. Clin Anat 2004;17:413-415.
Nakajima E, Iwata H, Iwase T, Murai H, Mizutani M, Miura S, Kato H: Four cases of chylous fistula after breast cancer resection. Breast Cancer Res Treat 2004;83:11-14.

7 Cong MH, Liu Q, Zhou WH, Zhu J, Song CX, Tian XS: Six cases of chylous leakage after axillary lymph node dissection. Onkology 2008;31:321-324.

8 Rijken A, Chaplin BJ, Rutgers EJT: Chyle in the drain after modified radical mastectomy: An easy manageable problem. Breast 1997;6:299-300.

9 van Pernis PA: Variations of the thoracic duct. Surgery 1949;26;806-809.

10 Greenfield J, Gottlieb MI: Variations in terminal portions of the human thoracic duct. Arch Surg 1956;73:955-999.

11 Bourgeois P, Munck D, Sales F: Anomalies of thoracic lymph duct drainage demonstrated by lymphoscintigraphy and review of the literature about these anomalies. Eur J Surg Oncol 2008;34:553-555.
2 Ayman SA: Lymphoscintigraphic demonstration of chylous leak after axillary lymph node dissection. Clin Nucl Med 2005;30;299-301.

13 Curcio A, Giuricin M, Lelli D, Falcini F, Nava MB, Folli S: Poland's syndrome and thoracic duct anomaly. Eur J Plast Surg 2009;32:155-156.

14 Sakman G, Parsak CK, Demircan O: A rare complication in breast cancer surgery: chylous fistula and its treatment. Acta Chir Belg 2007;107:317-319.

15 Abdelrazeq AS: Lymphoscintigraphic demonstration of chylous leak after axillary lymph node dissection. Clin Nucl Med 2005;30:299-301.

16 Rice DC, Emory RE Jr, McIlrath DC, Meland NB: Chylous fistula: an unusual occurrence after mastectomy with immediate breast reconstruction. Plast Reconstr Surg 1994;93:399-401. 